\title{
VALUE RELEVANCE OF BANK OPERATIONAL PERFORMANCE IN INDONESIA
}

\author{
Yulina Wong ${ }^{1}$ \\ AC Nielsen Indonesia
}

\begin{abstract}
The objective of the paper is to examine the value relevance of the disclosure of bank operating performance, as regulated by Bank of Indonesia. There are five operating performance ratios (CAR, NIM, BOPO, LDR, NPL) are examined in this study. The valuation model, then, also includes earnings and market condition, as control variables. The sample firms are bank that are listed in IDX during period 2005-2010, which consists of 144 observations. The result shows that some observations had performance measures below or above Bank of Indonesia's acceptable ratio ranges. The analysis shows that only NIM is regarded as a relevant valuation factor. CAR and BOPO are less relevant, when earnings are used as control variables. Earnings and market condition are positively related to market value of the banks. This concludes that market is indifferent in their valuation approach to banking industry and other industries.
\end{abstract}

Keywords: Banking, Operating performance, Valuation.

\section{INTRODUCTION}

In Indonesia, banks hold an important role in the movement of Indonesia economy. According to Pahlevie (2009), Economy crisis that hits Indonesian banks in 1997 were caused by enormous credit reserves and losses result from value difference in Rupiah exchange rate against the U.S. dollar that deteriorate of bank's capital. At that time, Non Performing Loan ratio (NPL) of commercial banks reach $50 \%$ and bank profit rate at $-18 \%$. Most banks were no longer able to

\footnotetext{
${ }^{1}$ AC Nielson Indonesia (abonkz@hotmail.com)
} 
fulfill its obligations, which results in banking crisis. Since then, Bank of Indonesia as a central bank imposed a tighter regulation.

Bank of Indonesia has set the provisions concerning the health rating of the bank performance with Surat Edaran Bank Indonesia No.6/23/DPNP May 31, 2004 which regulates rating system for commercial banks. As a result, Ariyanti (2010) stated that, banking performance was relatively stable throughout 2008 despite facing widespread pressure from the global financial crisis. Increased supervision and regulation by Bank of Indonesia as well as government and cooperation from public and other relevant authorities are the main reasons of stable bank performance. Cakti in Bisnis Indonesia (10 Dec 2010) confirmed that the growth of the banking industry in Indonesia is fantastic, the prospect of shares in bank industry are predicted to continue to rise in 2011. In 2010, Banking profit growth industry achieves 44\% year-on-year (Retnadi \& Hassim in Kontan, 20 Aug 2010). Increasing public confidence in Indonesian bank that maintain bank's performance during global economy crisis add interest to the author to observe bank's performance and their share price.

Government also regulates that all bank should disclose their financial ratio in the annual report as stated in Surat Edaran Bank Indonesia No 7/ 10 /DPNP, dated 31 March 2005. One of the mandatory disclosures for banks is the ratios measure the operational performance of bank companies. These ratios are monitor by Bank Indonesia and banks are mandatory to meet certain requirement ratios level. This information is crucial to the investor, and other users of annual report as bank report these financial ratios in financial highlight of their annual report. In efficient market theory, investors always include the available information as a factor in their investment decision which then reflects in the share price traded. This adds interest to the author to examine whether share price in the capital market contains the information of operational measures disclosed by bank.

According to Dimitropoulos, et. al. (2010), banks should provide relevance and reliable financial information as well as non-financial information in order for investors to make pricing decision. In recent years, value relevance becomes important concern to managers, investors, as well as other users of financial and non-financial 
information. Although, there have been many studies analyzing the performance of banking sector in Indonesia, to the author's knowledge, to date none relates the banks operating performance and valuation decision made by investors, using Indonesia data. Therefore, the objective of this research is to examine whether operational performance measurement that are required to be disclosed by bank companies are relevant for investor to value banking firms.

The paper is organized as follows. Section 2 aims to provide a general concept of the value relevance literature. Section 3 describes the data, variable, methodology used in the paper. Section 4 presents results regarding the value relevance of the operational performance measurements. Section 5, the final section, concludes and develops possible implications for banking industry.

\section{LITERATURE REVIEW}

\section{Bank Performance Ratio}

Good performance banks will increase the value of shares in the market and hence, increase the amount of funds from third parties. Good bank performance can be characterized by high levels of profitability, ability to pay dividend, developing business prospects, and comply with prudential banking regulation. One indicator of increasing public confidence in the bank is appreciation of value in stock price and increase the amount of funds from third parties. Trust and loyalty of publics is important factor for bank to develop a good business strategy. Performance of a particular bank can be measured by analyzing financial statements. Financial statement could provide real position of banks including its strength and weakness. It also shows the performance of bank management during a certain period (Ariyanti, 2010).

According to Surat Edaran Bank Indonesia No. 3/30/DPNP dated 14 December 2001, reports to be presented in the quarterly condensed financial statements at least consists of:

1) Balance Sheet

2) Calculation of Income and Retained Earnings

3) List of Commitments and Contingencies

4) Foreign Exchange and Derivatives Transactions 
5) Quality of Earning Assets and Information

6) Calculation of Minimum Capital Adequacy

7) Financial Ratios

Financial ratio provides information about financial position of an enterprise, especially if these ratios are compared with the benchmark ratio. Each type of financial ratios have their own usefulness to analyze different prospective of the firm Ariyanti (2010).

As bank have different characteristic with other industries, they have specific financial ratio. With Surat Edaran Bank Indonesia No 7/ 10 /DPNP dated 31 Maret 2005, bank are required to report financial ratio in five aspects, which are as follows:

\section{Capital ratio}

Capital ratio show bank's ability to maintain adequate capital and ability of bank management in identifying, measuring, supervise and control the risks that can affects the amount of bank capital. It associates with the bank financial leverage. Bank Indonesia required Indonesian bank to disclose Capital Adequacy Ratio and Fixed Assets to Capital ratio.

According to Purwasih (2010), Capital Adequacy Ratio (CAR) does not have a positive significant impact in the banking company's stock price that went public in Indonesia Stock Exchange. Other Malaysian research conduct by Elyor (2009) reveals that capital adequacy has positively but not significant affect their commercial banks performance during 2004 2008 periods. In contrast, Study by Nurhartanto (2010), stated that Capital Adequacy Ratio had a significant impact on share price.

\section{2. $\quad$ Asset Quality ratio}

Asset Quality shows the quality of assets relation to credit risk faced by banks. Productive assets qualities are assessed by determining their collectability. It is necessary to estimate the minimum size on earning assets which should be provided by banks to cover the risk of possible loss. Credit risk should be organized and control in certain rational limits (Ariyanti, 2010). In giving loan to debtor, bank should conduct an analysis of the ability of borrowers to repay their obligations. After they granted their loans, bank should monitor the use of the credit and the ability of their debtor in meeting obligation. 
Bank should review, assess and monitor their loans as to reduce credit risk.

In asset quality ratio, Bank Indonesia required Indonesian bank to disclose Non Performing Earning Assets, Non Performing Loans (gross and net), Allowance for Losses on Earning Assets to Required Allowance of Earning Assets and allowance for possible losses on earning asset. The most widely used to measure bank performance in controlling credit risk from debtor is Non Performing Loan ratio (NPL). Research by Angbazo (1997) stated that NPL doesn't have significant impact in the profit. Also, other study by (Nurhartanto, 2010) shows that NPL variable doesn't have impact in the share price. In contrary, Prior study stated in Elyor (2009) stated that NPL to total assets have the most significant impact to the Indian banks' performance.

\section{Profitability ratio}

There are number of indicators used to evaluate how profit related to the performance in banking industry. Bank performance in terms of profitability reflects its ability to support present and future operations. Profitability ratio that are required to be reported by Bank Indonesia are Return on Asset, Return on Equity, Net Interest Margin, and Operating Expenses to Operating Revenues (BOPO).

Afanasief et al (2004) stated that ROA, BOPO significantly affects profit in Brazilian bank. Prior study stated in Elyor (2009) shows that net interest margin (NIM) had significant impact on Indian bank's performance.

\section{Liquidity ratio}

Liquidity ratio is bank's capability to pay debt and unexpected financial needs. In order to meet their obligation, bank should hold non-earning asset. Efficient bank's liquidity supervision is able to meet customer loan demand and deposit withdrawal (Dimitropoulos et.al., 2010). Loan to Deposit is reported ratio that is required by Bank Indonesia.

According to Purwasih (2010), Loan to Deposit Ratio (LDR) did not significantly influence banking company's stock price. In contrary, research by Angbazo (1997) concluded that LDR have significant positive effect on profits. Also, Afanasief et al (2004) stated that LDR significantly affects profit in Brazilian bank. 


\section{Compliance ratio.}

The success of the bank's management is based on qualitative assessment

of management. Surat Edaran Bank Indonesia No.6/ 23 /DPNP about Bank Rating System of commercial bank, stated that a measurement of management factors should include compliance of the provisions and commitments to Bank Indonesia and other parties such as minimum reserve requirement, lending limit, and net open position. In Hays, Lurgio \& Gilbert (2009) study, they use salaries to average of asset as an assessment of management quality as salaries expense is a non-interest expense and could be manage by their management. Prior research stated in Elyor 2009 use interest expenses divided to total loans as a measurement of bank management quality.

\section{The value relevance of banking performance ratios}

In Indonesia banking industry, their operational performance could be measured by their financial ratios as Bank Indonesia used these ratios to rate their performance. The relevance of operational performance measurements can be explained by the signaling theory and the efficient market theory. Signaling theory explains reasons why firms have an incentive to report information to external parties, which is as to reduce information asymmetry. Reduction in information asymmetry affects the value of banking firms in gaining public confidence. Reduction information asymmetry reduces stock price volatility as bank report information to the public to give a clear signal and useful information for investment decisions, credit and similar decisions.

Efficient Market Theory is the basic theory of characteristic of an efficient capital market where investors have a knowledge and information are available to investors so that they can react quickly on new information that ultimately cause stock prices to adjust quickly and accurately. Efficient Market Theory states that investors always include available information as factor in their decision which will reflect in share price traded. Thus, the share price prevailing on the capital market already contains factor of the information. Characteristics of a capital market efficient are knowledgeable investors with available information to react quickly on new information that ultimately caused the stock price adjust quickly and accurately. So share price will reflect from the information published 
by bank. Good bank performance will increase their share price, and poor bank performance will decrease bank share price (Purwasih, 2010).

To test the relevance of financial statement, they use component of financial statement as their variables. There have been many prior research of value relevance in bank industry using different measures. Variables used in prior researches by Dimitropoulos et.al., (2010) and Agostino, Drago and Silipo (2008), and other researchers are earnings, cash flow, and book value of equity.

Study by Dimitropoulos et.al. (2010) examine relevance of earning and cash flow, also considering bank's risk such as interest rate risk, credit risk, liquidity risk and solvency risk, using Greek bank's data analysis over a period of ten years (1995-2004), observed that earning provide higher relevance than cash flow in determining share return since change in earning have positive impact in stock return. Interest rate risk has a positive but not significant influence on stock return but on the contrary solvency risk, credit risk and liquidity risk have negative impact on the stock return.

Research by Agostino, Drago and Silipo (2008) about value relevance of IFRS using 221 European listed Banks from period 2000 to 2006 concluded that there is an increasing impact on earnings before and after convergence of IFRS, while book value of equity had a decreasing and insignificant impact. Generally, bank performances are measured by financial ratio. Based on bank financial statements, financial ratio could be calculated as a ratio to measure bank's condition. Study by (Wirnkar \&Tanko, 2008) analyzes the adequacy of CAMEL ratio in determining 11 commercial banks in capturing in Nigeria over a period 1997 - 2005. The finding shows that these factors do not have ability in determining overall performance of a bank as all hypotheses are rejected in this study.

\section{Hypothesis development}

This study aims to examine the value relevance of bank performance measurements, which are indicated by major banking performance ratios (CAR, NPL, NIM, BOPO, and LDR) as well as earnings and economic conditions. 
CAR (Capital Adequacy Ratio) is the ratio of bank's capital required to cover risks losses arising from investment that contain market and credit risk. All banks in Indonesia are required to provide a minimum capital of $8 \%$ of Capital Adequacy Ratio by Surat Edaran Bank Indonesia No.6/23/DPNP May 31, 2004.

Effect of CAR on the value of banking firms can be explained by the signaling theory and the efficient market theory. Signaling theory explains reasons why firms have an incentive to report information to external parties, which is as to reduce information asymmetry. Reduction in information asymmetry affects the value of banking firms in gaining public confidence. Reduction information asymmetry reduces stock price volatility as bank report information to the public to give a clear signal and useful information for investment decisions, credit and similar decisions.

Efficient Market Theory is the basic theory of characteristic of an efficient capital market where investors have a knowledge and information are available to investors so that they can react quickly on new information that ultimately cause stock prices to adjust quickly and accurately. Efficient Market Theory states that investors always include available information as factor in their decision which will reflect in share price traded. Thus, the share price prevailing on the capital market already contains factor of the information. Characteristics of a capital market efficient are knowledgeable investors with available information to react quickly on new information that ultimately caused the stock price adjust quickly and accurately. So share price will reflect from the information published by bank. Good bank performance will increase their share price, and vice versa (Purwasih, 2010).

Capital Adequacy Ratio is an indicator that shows the ability of available bank's equity covers the declining in bank assets due to providing funds to accommodate the purposes of business development and risk of loss funds caused by the operations of the bank. The higher CAR shows that a bank has greater equity to cover risks that may affect to the amount of bank capital, it implies the better the condition of a bank, hence increases investor confidence in the banking company (Ponco, 2008). 
Investor confidence will have an effect on their valuation process. This research include first hypothesis to observe CAR relevance, which is as follows:

\section{H1: CAR are positively related to value of banking firms}

Non-performing loans can be defined as a loan repayment difficulties due presence of factors beyond the control of debtor. This ratio indicates the asset quality ratio, it measure the ability of bank management in managing their credit (Nurhartanto, 2010). According to Bank Indonesia Regulation Number 6/10/PBI/2004 dated April 12, 2004 on Rating System Health Commercial Bank confirmed that NPL above $5 \%$ are considered "unhealthy" bank. NPL ratio calculates the level of nonperforming loan compared to its total loan. The higher the value of NPL ratio shows that greater non performing loan compared to total loan. It implies a worse credit management by the banks (Wirnkar \&Tanko, 2008). Hence, it will decrease investor confidence in the banking company which will have a negative effect on their valuation process

Therefore, based on the aforementioned discussion above, the author would like to test second hypothesis which can be formulated as follows:

\section{H2: NPL are negatively related to value of banking firms}

According to BI Regulation No. 5 / 8 in 2003, market risk is the type of risks that exist in the banking industry. Market risk is the combined risk that is formed by changes in interest rates, changes in exchange rates and factors that determine stock market prices, or equity, and commodities. Bank is affected by the factors that form the price in capital market such as interest rates. Interest rate risk impact their business structures as they perform lending activities and revenue savings.

Bank Indonesia suggests minimum NIM ratio should be above 1,5\% to meet the criteria of health bank. Net Interest Margin (NIM) is an earning aspect ratio that shows bank management capability in managing its productive assets to generate net interest income. Net interest income derived from Interest income less interest expense. 
The greater this ratio means there is an increase in interest income on earning assets managed by banks.

So the greater Net Interest Margin (NIM) ratio means the greater the bank's profitability obtained by the bank, which means that the bank performance has improved, which will positively impact their valuation process (Ponco, 2008).

Hypothesis 3:

H3: NIM are positively related to value of banking firms

Operating efficiency is measured by comparing the total cost of operation with a total operating income or often called BOPO. BOPO ratio reflects the lack of suppress the ability of banks in operational costs which can cause losses as the bank is less efficient in managing its business. (Bank Indonesia, 2008). Bank Indonesia confirmed that BOPO ratio above $96 \%$ is categorized as inefficient in running its operations. The ratio is used to measure ability of bank management in controlling operating costs of operating income. Operating costs are costs incurred by banks in connection with their activities, while operating income is all forms of income derived from activities of the bank. The smaller BOPO ratio means more efficient in running their operations, which implies better the condition of a bank, increases investor confidence in the banking company and will have an effect on their valuation process (Ariyanti, 2010). Therefore, the fourth hypothesis is states as follow,

H4: BOPO are negatively related to value of banking firms

LDR (Loan to Deposit ratio) shows how a bank has tied its deposit in less liquid assets. It is a ratio to assess the liquidity risk of a bank. Liquidity risk is inability of banks to pay back withdrawals by depositors by relying on credit provided as a source of liquidity. LDR can be used to assess the management strategy of a certain bank. The higher Loan to Deposit Ratio shows more risky bank liquidity conditions, while lower LDR shows a lack of effectiveness of the bank in channeling its bank loans which means loss of opportunity to gain profit (Purwasih, 2010) 
Effective liquidity management should confirm to public that the bank is safety and able to pay its obligation (confidence factor). Bank with effective liquid management provide safety and a sense of confidence to their investors which could be classified as good news to market while highly illiquid is classified as bad news to investors as bank with no confidence is sentence to failure. (Dimitropoulos, 2010). The higher LDR ratio means the lower ability of a bank in its liquidity which will decrease investor confidence and have a negative effect on their valuation process. (Wirnkar \&Tanko, 2008).

Bank Indonesia suggests maximum 100\% LDR to meet the criteria of health bank. Based on the above discussion, the author would like to test the last hypothesis:

\section{H5: LDR are negatively related to value of banking firms}

Study by Easton and Harris (1991) result suggests that earnings have a significant impact in security valuation. Also, Dimitropoulos (2010) suggest that earnings have higher level of significance in explaining share return compared to cash flows as change in earnings affect share returns positively. The value relevance of earning in determining share price could be observed from correlations between share return and earning. High explanatory power of earning could be specified from the level of contribution of earning to investor (Lev, 1989). Higher earnings could be regarded as better condition of a company, higher share price and hence, bring positive effect to the value of the company. Therefore the sixth hypothesis that the author would like to test is:

\section{H6: Earnings are positively related to value of banking firms}

Investor will buy/hold or sell shares according to market conditions. Here, dummy variable for economic conditions is used to control market condition. DEC is dummy variable for economic condition to control the market condition. It would be valued 1 when IHSG annual return is positive and 0 when IHSG annual return is negative. In bullish market condition which indicates by positive DEC, investor tend to invest more money in capital market, as they perceived that public companies' share price will rise. Hence, it will have positive impact on investor valuation. 
Therefore last hypothesis is as stated below:

H7: DEC are positively related to value of banking firms

\section{RESEARCH DESIGN}

\section{Sample and Data Descriptions}

This study use data of listed bank companies during period 20052010. The final sample research will observe 30 bank companies with 144 firm years for data analysis in this research. Data are collected from published financial statement from Indonesian Stock Exchange (IDX) and also their companies' website. The dependent variable used is the value of the bank companies which is indicated by their share price deflated by their book value of equity. Stock price and the book value of equity used in this research is the closing share price of each bank firms at end of March during study period (2005-2010) as public companies usually have published their financial report in their company website as well as in IDX website.

In this research, independent variable used is the operational performance measure of the bank companies, which is indicated by bank's financial ratio. There are 5 most widely used ratios that represent bank's financial ratios. These 5 ratios measure capital, asset quality, profitability and liquidity aspects of a company. These independent variables are:

\section{CAR (Capital Adequacy Ratio)}

Capital Adequacy Ratio show bank's ability to maintain adequate capital and ability of bank management in identifying, measuring, supervise and control the risks that can arise affects the amount of bank capital. According to Surat Edaran BI No.6/23/DPNP, it is the calculation of capital and risk weighted assets conducted under the provisions of minimum capital adequacy and the formula for calculating CAR is:

CAR:

Total Capital

Risk-weighted assets (ATMR) 


\section{NPL (Non Performing Loan)}

Non Performing Loan is a ratio of nonperforming and doubtful loans divided by total credit given to third parties (but not including credit to other banks). The formula for calculating ROA is:

NPL: $\quad$ Nonperforming loans

Total credit

\section{NIM (Net Interest Margin)}

Net interest income is interest income less interest expenses, and earning asset calculated is interest-bearing assets.

The formula for calculating NIM is:

NIM: $\quad$ Net interest income

Average earning assets

\section{BOPO (Operational Income to Operational Expense)}

According to Surat Edaran BI No.6/23/DPNP, BOPO represents the ratio of operating expense to operating revenue, which is formulated as follows:

BOPO: $\quad$ Total operating expenses

Total operating income

\section{LDR (Loan to Deposit Ratio)}

LDR is a ratio of total credit given to parties third (excluding credit to other banks) divided by third party funds include demand deposits, savings deposits, time deposits (excluding inter-bank).

The formula for calculating LDR is:

LDR: $\quad$ Credit

Third party funds 
This research uses 2 control variables which are net income (E/BV) and dummy variable for economic condition (DEC). Easton and Harris (1991) and Dimitropoulos (2010) studies suggest that earnings have a significant impact in security valuation. These results clarify that earnings could be the explanatory variable for share returns. In this research, Earning is a control variable while size is used as a deflator.

Earning (net income) is a direct measure of firm's performance. Since earnings figure varies according to size of the firms, the measure used for earnings is earnings deflated by book value of equity at the end of year.

DEC is dummy variable for economic condition to control the market condition. It would be valued 1 when IHSG annual return is positive and 0 when IHSG annual return is negative. The formula for calculating IHSG return is:

IHSG at year end - IHSG at beginning of year

IHSG at beginning of year

\section{Data analysis}

As other quantitative studies, this study will use descriptive and correlation analyses to describe the sample characteristic related to the research topic. Then, to test the hypothesis, this study will employ the multiple regression model.

The first model uses only the bank performance ratio as independent variables and market to book value as the dependent variable. The first model is expressed as equation (1)

$$
\frac{M V}{B V_{i t}}=\beta_{0}+\beta_{1} C A R_{i t}+\beta_{2} N P L_{i t}+\beta_{3} N I M_{i t}+\beta_{4} B O P O_{i t}+\beta_{5} L D R_{i t}+\varepsilon_{i t}
$$

Then, adding the control variables, research model 1 is extended to research model 2 , as stated in equation 2 below, 
$\frac{M V}{B V_{i t}}=\beta_{0}+\beta_{1} C A R_{i t}+\beta_{2} N P L_{i t}+\beta_{3} N I M_{i t}+\beta_{4} B O P O_{i t}+\beta_{5} L D R_{i t}+\beta_{6} E / B V_{i t}+\beta_{7} D E C_{i t}+\varepsilon_{i t} \quad$ (1)

Given that:

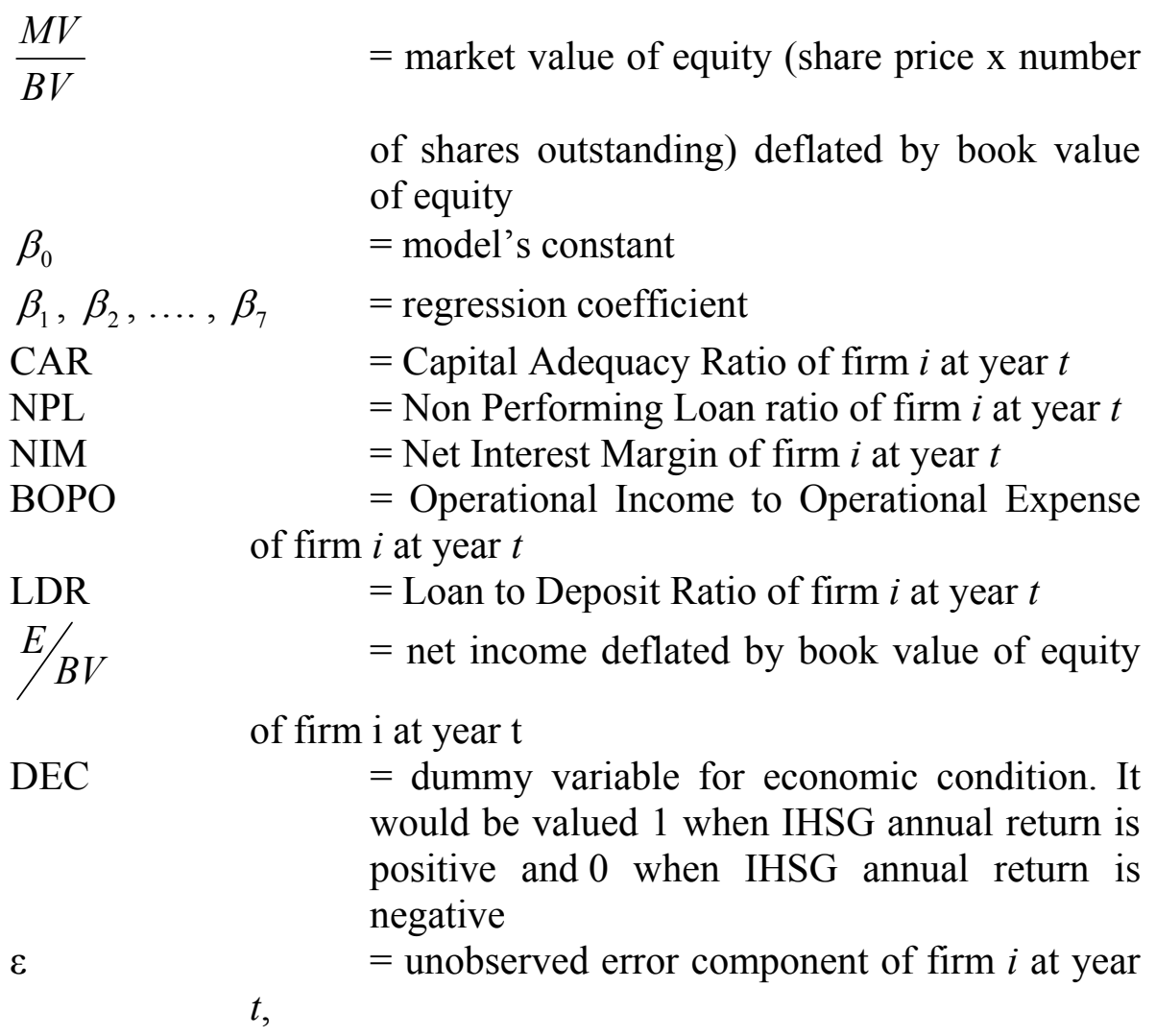




\section{RESULT}

Descriptive statistic presented in Table 1 below includes mean, median, standard deviation, maximum and minimum value of the samples.

Table 1. Descriptive Statistic

\begin{tabular}{|l|l|l|l|l|l|c|}
\hline Variable & $\mathrm{N}$ & Minimum & Maximum & Mean & Median & $\begin{array}{c}\text { Std. } \\
\text { Deviation }\end{array}$ \\
\hline MV/BV & 144 & 0.2995 & 5.0238 & 1.8585 & 1.6816 & 1.0900 \\
\hline CAR & 144 & 0.0934 & 0.5037 & 0.1824 & 0.1592 & 0.0744 \\
\hline NPL & 144 & 0.0000 & 0.5096 & 0.0413 & 0.0293 & 0.0526 \\
\hline NIM & 144 & 0.0177 & 0.1237 & 0.0583 & 0.0530 & 0.0216 \\
\hline BOPO & 144 & 0.6430 & 1.5750 & 0.8678 & 0.8618 & 0.1136 \\
\hline LDR & 144 & 0.4022 & 1.0842 & 0.7247 & 0.7473 & 0.1599 \\
\hline E/BV & 144 & -0.3630 & 0.2852 & 0.0975 & 0.0989 & 0.1001 \\
\hline DEC & 144 & - & - & 0.8194 & - & 0.3860 \\
\hline
\end{tabular}

The descriptive statistics shows that of 144 observation, there are some observations that do not meet the ratios target as regulated by Bank of Indonesia, such as NPL ratio, and BOPO. However, other ratios are in Bankd of Indonesia acceptable ranges.

The study uses correlation matrix to identify the possibility of multicollinearity problem in the research data. This study uses Pearson correlation matrix, which presented as below:

Table 2. Pearson Correlation Matrix

\begin{tabular}{|l|l|l|l|l|l|l|l|l|l|}
\hline \multicolumn{2}{|l|}{} & MV/BV & CAR & NPL & NIM & BOPO & LDR & E/BV & DEC \\
\hline MV/BV & Correlation & 1 & & & & & & & \\
$\begin{array}{l}\text { Sig. (2- } \\
\text { tailed) }\end{array}$ & & & & & & &
\end{tabular}




\begin{tabular}{|c|c|c|c|c|c|c|c|c|c|}
\hline & & $\mathrm{MV} / \mathrm{BV}$ & CAR & NPL & NIM & BOPO & LDR & E/BV & DEC \\
\hline CAR & $\begin{array}{l}\text { Correlation } \\
\begin{array}{l}\text { Sig. } \\
\text { tailed) }\end{array}\end{array}$ & $\begin{array}{l}-0.017 \\
0.842\end{array}$ & 1 & & & & & & \\
\hline NPL & $\begin{array}{l}\text { Correlation } \\
\begin{array}{l}\text { Sig. (2- } \\
\text { tailed) }\end{array}\end{array}$ & $\begin{array}{l}-0.034 \\
0.689\end{array}$ & $\begin{array}{l}0.088 \\
0.297\end{array}$ & 1 & & & & & \\
\hline NIM & $\begin{array}{l}\text { Correlation } \\
\text { Sig. (2- } \\
\text { tailed) }\end{array}$ & $\begin{array}{l}.306^{* *} \\
0.000\end{array}$ & $\begin{array}{l}-0.011 \\
0.897\end{array}$ & $\begin{array}{l}-0.126 \\
0.132\end{array}$ & 1 & & & & \\
\hline BOPO & $\begin{array}{l}\text { Correlation } \\
\text { Sig. (2- } \\
\text { tailed) }\end{array}$ & $\begin{array}{l}-.291 \\
0.000\end{array}$ & $\begin{array}{l}-0.136 \\
0.104\end{array}$ & $\begin{array}{l}.636^{* *} \\
0.000\end{array}$ & $\begin{array}{l}-.304 \\
0.000\end{array}$ & 1 & & & \\
\hline LDR & $\begin{array}{l}\text { Correlation } \\
\text { Sig. (2- } \\
\text { tailed) }\end{array}$ & $\begin{array}{l}0.050 \\
0.553\end{array}$ & $\begin{array}{l}-.253^{* *} \\
0.002\end{array}$ & $\begin{array}{l}-0.125 \\
0.135\end{array}$ & $\begin{array}{l}.415^{* *} \\
0.000\end{array}$ & $\begin{array}{l}0.108 \\
0.196\end{array}$ & 1 & & \\
\hline $\mathrm{E} / \mathrm{BV}$ & $\begin{array}{l}\text { Correlation } \\
\text { Sig. (2- } \\
\text { tailed) }\end{array}$ & $\begin{array}{l}.358^{* *} \\
0.000\end{array}$ & $\begin{array}{l}-0.054 \\
0.518\end{array}$ & $\begin{array}{l}-.546^{* *} \\
0.000\end{array}$ & $\begin{array}{l}.298^{* *} \\
0.000\end{array}$ & $\begin{array}{l}-.862^{* *} \\
0.000\end{array}$ & $\begin{array}{l}-0.078 \\
0.351\end{array}$ & 1 & \\
\hline $\mathrm{DEC}$ & $\begin{array}{l}\text { Correlation } \\
\text { Sig. (2- } \\
\text { tailed) }\end{array}$ & $\begin{array}{l}0.157 \\
0.061\end{array}$ & $\begin{array}{l}0.053 \\
0.529\end{array}$ & $\begin{array}{l}0.093 \\
0.270\end{array}$ & $\begin{array}{l}-0.072 \\
0.394\end{array}$ & $\begin{array}{l}-0.008 \\
0.926\end{array}$ & $\begin{array}{l}-0.142 \\
0.090\end{array}$ & $\begin{array}{l}0.027 \\
0.749\end{array}$ & 1 \\
\hline
\end{tabular}

The criterion for multicollinearity problem is the availability of variable which is correlated over 0.8 or -0.8 . From table 2 , it can be derived that there are correlated variables over -0.8 (BOPO with E/BV for -0.862). So, this study will perform extended analysis with same regression model, but excluding $\mathrm{E} / \mathrm{BV}$ variable. This study has exclude $\mathrm{E} / \mathrm{BV}$ variable because $\mathrm{BOPO}$ is the main variable, while $\mathrm{E} / \mathrm{BV}$ is the control variable in this regression model. 
This research use White t-test to adjust possibility of heteroscedasticity problem. Table 3 shows regression output for model 1:

Table 3. Regression results for Model 1

\begin{tabular}{|c|c|c|c|}
\hline \multicolumn{4}{|c|}{$\begin{array}{l}\text { Dependent Variable: MV_BV } \\
\text { Method: Panel Least Squares } \\
\text { Sample: } 1144 \\
\text { Total panel (unbalanced) observations: } 144\end{array}$} \\
\hline Variable & Coefficient & $\begin{array}{l}\text { White t- } \\
\text { Statistic }\end{array}$ & Prob. \\
\hline $\mathrm{C}$ & $4.0319 * *$ & 7.2221 & 0.0000 \\
\hline CAR & $-1.304 *$ & -1.8573 & 0.0654 \\
\hline NPL & 5.0287 & 1.522 & 0.1303 \\
\hline NIM & $10.6757 *$ & 1.8649 & 0.0643 \\
\hline $\mathrm{BOPO}$ & $-3.8022 * *$ & -8.769 & 0.0000 \\
\hline LDR & 0.2388 & 0.4401 & 0.6605 \\
\hline R-squared & 0.1998 & F-statistic & $5.6999 * *$ \\
\hline Adjusted R-squared & 0.1647 & Prob(F-statistic) & 0.0000 \\
\hline
\end{tabular}

Note: * significant at $\alpha=10 \%$, ** significant at $\alpha=1 \%$,

From the result above, it can be concluded that first hypothesis which stated CAR are positively related to $\mathrm{MV} / \mathrm{BV}$ is rejected. The table shows a negative relation between $\mathrm{CAR}$ and $\mathrm{MV} / \mathrm{BV}$. It implies that the higher the CAR will result in less value of the bank share. Second working hypothesis which stated NPL are negatively related to $\mathrm{MV} / \mathrm{BV}$ is also rejected. Ponco (2008) states that presence of nonperforming loans causes bank loans do not provide much return to banks. During the research study, there are 21 observations exceeding the maximum percentage of NPL ratio which is about 5\%. From the descriptive statistic, Maximum NPL ratio shows value of $50.96 \%$ by Bank Pundi Indonesia (Purnomo, 2010). This insignificant result might be driven by these extreme values. 
The third working hypothesis stated that Net Interest Margin (NIM) are positively related to $\mathrm{MV} / \mathrm{BV}$ is accepted. Investors still use NIM ratio as their valuation because NIM reflects the operational result which directly affect net income.

The fourth working hypothesis is supported as BOPO has a negative significant effect in $\mathrm{MV} / \mathrm{BV}$. This result imples that the higher operational expenses, relatively, to operational income, will results in lower value of the share.

The Fifth working hypothesis which stated that LDR has negative effect to $\mathrm{MV} / \mathrm{BV}$ is rejected as LDR has a positive insignificant effect on $\mathrm{MV} / \mathrm{BV}$. In the observation, there is a high gap between minimum and maximum value of LDR ( $40 \%$ and $108 \%)$. This indicates that some banks are less optimal in channeling their third-party funds but on the other side, there are other banks provide excessive credit. This is the reason why investors do not pay much attention to LDR ratio in their valuation. So it does not have significant influence on market to book ratio.

The partial test of banking Operational performance measurement indicates that CAR, NIM, and BOPO, have significant effects on bank valuation in Indonesian banking industry. These three ratios reflects more on the solvability (CAR) and profitability (NIM and BOPO) of the banks. This suggests that market are indifferent on their valuation approach on the shares of banking industry and other industries.

To test the effect of control variables, the model 2 is analyzed. The extended regression result is presented in table 4, below:

Table 4. Regression result for Model 2

\begin{tabular}{|c|c|c|c|}
\hline \multicolumn{4}{|c|}{$\begin{array}{l}\text { Dependent Variable: MV_BV } \\
\text { Method: Panel Least Squares } \\
\text { Total panel (unbalanced) observations: } 144\end{array}$} \\
\hline Variable & Coefficient & $\begin{array}{l}\text { White t- } \\
\text { Statistic }\end{array}$ & Prob. \\
\hline $\mathrm{C}$ & 0.8257 & 0.5703 & 0.5694 \\
\hline
\end{tabular}




\begin{tabular}{|l|l|l|l|} 
CAR & -0.308 & -0.384 & 0.7016 \\
\hline NPL & 4.758 & 1.6436 & 0.1026 \\
\hline NIM & $9.797^{*}$ & 1.8836 & 0.0618 \\
\hline BOPO & -0.7449 & -0.626 & 0.5324 \\
\hline LDR & 0.3414 & 0.6503 & 0.5166 \\
\hline E_BV & $3.8893^{* *}$ & 2.9429 & 0.0038 \\
\hline DEC & $0.4163^{* *}$ & 6.1186 & 0.0000 \\
\hline \multicolumn{4}{|l}{} \\
\hline R-squared & 0.2281 & F-statistic & $5.7418^{* *}$ \\
\hline Adjusted R-squared & 0.1884 & Prob(F-statistic) & 0.0000 \\
\hline
\end{tabular}

Note: $*$ significant at $\alpha=10 \%, * *$ significant at $\alpha=1 \%$,

After controlling for earnings and negative earnings, the above table shows similar results to the previous test. Some differences are, firstly, the disappearing impact of CAR to share value. Pahlevie (2009) and Ariyanti (2010) studies, CAR shows an insignificant result to banks earning. The reason of CAR's insignificant result is because bank's owner did not disburse additional capital funds in the period of research as the ratio of CAR is relatively constant. In this research, CAR of each bank also relatively constant from one period to another. Secondly, BOPO also lost their significance in this extended model. The possible reason is a statistical issue of multicollinearity as shown in the correlation matrix (table 2). Meanwhile, NIM keeps its significance showing that market does use it to value the banks' share.

The sixth working hypothesis stated that Earning to book ratio (E/BV) are positively related to $\mathrm{MV} / \mathrm{BV}$ is accepted. Investors use bank net income for their valuation as earnings or net income is a direct measurement of a company performance. This result is similar to Easton and Haris (1991) and Dimitropoulos (2010). Dimitripoulos (2010) suggest that earnings have higher level of significance in explaining share return compared to cash flows as change in earnings affect share returns positively. The last hypothesis is dummy variable for economic condition (DEC) are positively related to $\mathrm{MV} / \mathrm{BV}$ is accepted. Investors will buy/hold or sell shares according to market conditions. Bullish market condition which indicates by positive DEC 
will lead investor to invest their money in capital market, and will have positive impact on investor valuation, thus, their MV/BV ratio.

\section{CONCLUSION}

As stated in Surat Edaran Bank Indonesia No 6/10/PBI/2004, banks are required to perform bank rating assessment on a quarterly basis. Bank companies who violate this regulation could be penalized according to Undang-Undang No 10 (1998), Article 52. These penalties would be written warning, suspension of bank activities, and also inclusion of list of names which are prohibited to be their board of director or shareholders. From these penalties and regulations, stockholders might assume that all bank companies have follow Bank Indonesia regulation regarding the health assessment of bank performance. However, from the analysis, it can be concluded that, during the observation period, there are still some banks that have ratios under or above Bank of Indonesia acceptable ratio targets.

The results also provide evidence that only NIM ratio is relevant for market to value the shares of banks. Other ratios, such as BOPO and CAR become irrelevant, when earnings is introduced to the model. Therefore it could be concluded that market is indifferent in its valuation approach on banking industry and other industries.

The observation shows that all bank firms have exceed the minimum amount of CAR ratio. Since the higher CAR could lower the valuation of banking firms. Therefore, this study recommends Bank Indonesia and bank management to limit the maximum amount of CAR. This study also recommends further research to observe the maximum amount of CAR.

This study uses 7 variables (CAR, NPL, NIM, BOPO, LDR, E/BV and DEC), which could explain $18.84 \%$ variance of $\mathrm{MV} / \mathrm{BV}$. Thus, $81.16 \%$ of $\mathrm{MV} / \mathrm{BV}$ values could be explained by other variables that are not included in this regression model.

Bank Indonesia regulates bank to disclose their bank financial ratios, which consist of 14 ratios. This study would like to recommend other parties to conduct further research using all these ratios to obtain more 
accurate result. Also, this study would like to recommend other researchers to use different valuation, other than these ratios. Further research should also expand more sample period to attain more accurate result.

\section{REFERENCE}

Afanasief ,Lhacer \& Nakane, (2004), “The Determinants of Bank Interest Spread in Brazil,” JEL Classification: G21;E43; E44.

Agostino, Drago and Silipo, 2008, The Value Relevance of IFRS in the European Banking Industry.

Angbazo, L (1997), Commercial Bank Net Interest Margin, Default Risk, Interest-Rate Risk, and Off-Balance Sheet Banking. Journal of Banking and Finance, 21, 55-87.

Ariyanti (2010), Analisis pengaruh CAR, NIM, LDR, NPL, BOPO, ROA dan Kualitas Aktifa Produktif terhadap Perubahan Laba pada Bank Umum di Indonesia, [Master thesis], Indonesia: Diponegoro University.

Artwienda (2009), Analisis Pengaruh CAR, NPL, BOPO, NIM, dan LDR Terhadap Perubahan Laba, Indonesia: Diponegoro University.

Bank Indonesia (2008), 'ikhtisar perbankan' from Central Bank of Republic of Indonesia, www.bi.go.id.

Bank Indonesia rules and regulation No. 3/22/PBI/2001 about Transparency of banks financial condition and No.6/10/PBI/2004 April 12, 2004 about Bank Rating System of commercial bank from Central Bank of Republic of Indonesia, www.bi.go.id.

Bank Indonesia No. 3011/KEP/DIR dated 30 April 1997 on Procedure Bank Health Assessment method known as CAMEL (Capital, Assets, Management, Earning, Liquidity) from Central Bank of Republic of Indonesia, www.bi.go.id. 
Bank Indonesia Surat Edaran No. 3/30/DPNP dated 14 December 2001 , No.6/ 23 /DPNP dated May 31, 2004 about Bank Rating System of commercial bank, No 7/ 10 /DPNP dated 31 March 2005, from Central Bank of Republic of Indonesia , www.bi.go.id.

Barth.E, 1994. Fair Value Accounting: Evidence from Investment Securities and the Market Valuation of Banks. The Accounting Review, Vol 69, No 1, p 1-25.

Cakti in Bisnis Indonesia (10 Dec 2010) ,Perbankan beri kinerja menjanjikan, message posted to $\underline{\text { http://bataviase.co.id/node/488437 }}$

Cooper \& Schindler, 2003, Business Research Methods $8^{\text {th }}$ edition. New York: MCGraw Hill.

Copeland, Koiler, and Murrin, 2000, Valuation: Measuring and Managing the Value of Companies, $3^{\text {rd }}$ Edition. Mckinsey\&Company.Inc.

Dimitropoulos, Asteriou, Koumanakos, 2010. The relevance of earnings and cash flows in a heavily regulated industry: Evidence from the Greek banking sector. Journal of Advances in Accounting, incorporating Advances in International Accounting 26 (2010) 290-303.

Dontoh, Radhakrishnan, Ronen (2007), Is stock price a good measure for assessing.

Dontoh, Radhakrishnan, Ronen (2004) The declining value relevance of accounting, information and non information based trading, Contemprorary accounting research, Winter 2004, pg 795.

Easton and Harris (1991), Earnings As an Explanatory Variable for Returns, Journal of Accounting Research, Vol. 29, No. 1 (Spring, 1991), pp. 19-36. 
Elvor (2009), Factors Affecting the Performance of Foreign Banks in Malaysia [Master Thesis] Malaysia: University Utara Malaysia.

Financial Accounting Standards Board (FASB) Concepts Statement No.2.

Francis \& Schipper (1999), Have Financial Statements Lost Their Relevance?, Journal of Accounting Research, Vol. 37, No. 2 (Autumn, 1999), pp. 319-352.

Hadad, Sugiarto, Purwanti3, Hermanto, Arianto (September 2003), Kajian Mengenai Struktur Kepemilikan Bank di Indonesia . JEL Classification : G21, G32.

Hays, Lurgio \& Gilbert (2009), Efficiency Ratios and Community Bank Performance, Journal of Finance and Accountancy.

Hida El - detikFinance , Kenalkan Logo Baru Century Resmi Jadi Bank Mutiara (03/10/2009) retrieved from http://www.detikfinance.com/read/2009/10/03/201513/121460 4/5/century-resmi-jadi-bank-mutiara.

(Hunjak \& Jakovčević, 2001). AHP based model for bank performance evaluation and rating, ISAHP 2001, Berne, Switzerland, August 2-4, 2001.

IASB (International Accounting Standard Board), IASB Framework, paras. 12-14), Para. 38, Para. 5).

Law of the Republic of Indonesia, number 10, year 1998, banking definition.

Lev (1989), On the Usefulness of Earnings and Earnings Research: Lessons and Directions from Two Decades of Empirical Research. Journal of Accounting Research, Vol. 27, Current Studies on The Information Content of Accounting Earnings (1989), pp. 153-192. 
Mahardian (2008), Analisis Pengaruh Rasio CAR, BOPO, NPL, NIM dan LDR terhadap Kinerja Perbankan, [S1 Thesis], Indonesia: Diponegoro University.

Nurazi and Evans (2005) "An Indonesian Study of the Use of CAMEL(S) Ratios as Predictors of Bank Failure," Journal of Economic and Social Policy: Vol. 10: Iss. 1, Article 6. Available at: http://epubs.scu.edu.au/jesp/vol10/iss1/6.

Nurhartanto (2010), Pengaruh Rasio Camels terhadap Harga Saham Periode 2004-2009, from Gunadarma University database.

Pahlevie (2009), Analisis pengaruh CAR, NPL, BOPO, NIM, EAQ, LDR terhadap perubahaan, Indonesia: Diponegoro University.

Ponco (2008), Analisis pengaruh CAR, NPL, BOPO, NIM, LDR terhadap ROA (Studi Kasus Pada Perusahaan Perbankan yang Terdaftar di Bursa Efek Indonesia Periode 2004-2007), Indonesia: Diponegoro University.

Purnomo, Detik Finance (30 Sept 2010), Disuntik Recapital, NPL Bank Pundi Turun Tajam , message posted to http://us.detikfinance.com/read/2010/09/30/172246/1452500/5 /disuntik-recapital-npl-bank-pundi-turun-tajam.

Purwasih (2010), Pengaruh Rasio CAMEL Terhadap Perubahan Harga Saham Perusahaan Perbankan yang Go Public di BEI [S1 Thesis], Indonesia: Diponegoro University.

PSAK No. 31 in the Financial Accounting Standards (1999: 31.1), definition of bank.

Retnadi \& Hassim in Kontan, 20 Aug 2010, Kinerja Perbankan Semakin Bersinar, message posted to http://ekonomi.kompasiana.com/moneter/2010/08/27/kinerjaperbankan-semakin-bersinar/.

Standar Akutansi Keuangan (SAK) No. 1, the objective of financial statement. 
Sekaran, 2003, Research Method for Business $4^{\text {th }}$ edition, USA : John Wiley \& Sons,Inc.

Value-relevance of earnings? An empirical test. Retrieved 23 January 2007, Springer-Verlag.

Weygandt, Chalmers, Mitrione, Fyfe, Kieso, Kimmel, 2005, Principles of Financial Accounting, Australia: John Wiley \& Sons Ltd.

Wirnkar \&Tanko, (2008) CAMEL(S) and Bank Performance Evaluation: The Way Forward, Electronic copy available at: http://ssrn.com/abstract=1150968. 